九州大学学術情報リポジトリ

Kyushu University Institutional Repository

\title{
Thermodynamic Analysis of Adsorption Cooling Cycle using Ethanol-Surface treated Maxsorb III Pairs
}

\section{Uddin, Kutub}

Interdisciplinary Graduate School of Engineering Sciences, Kyushu University | 1nternational Institute for Carbon-Neutral Energy Research (WPI-I2CNER), Kyushu University

El-Sharkawy, Ibrahim I.

Faculty of Engineering Sciences, Kyushu University | Mechanical Power Engineering Department, Mansoura University | International Institute for Carbon-Neutral Energy Research (WPI-I2CNER), Kyushu University

Miyazaki, Takahiko

Faculty of Engineering Sciences, Kyushu University | International Institute for CarbonNeutral Energy Research (WPI-I2CNER), Kyushu University

Saha, Baran Bidyut

Interdisciplinary Graduate School of Engineering Sciences, Kyushu University | 1nternational Institute for Carbon-Neutral Energy Research (WPI-I2CNER), Kyushu University

他

https://doi.org/10.5109/1440973

出版情報: Evergreen. 1 (1)，pp.25-31，2014-03. Green Asia Education Center バージョン：

権利関係 : 


\title{
Thermodynamic Analysis of Adsorption Cooling Cycle using Ethanol-Surface treated Maxsorb III Pairs
}

\author{
Kutub Uddin ${ }^{1,4}$, Ibrahim I. El-Sharkawy ${ }^{2,3,4}$, Takahiko Miyazaki ${ }^{2,4}$ \\ Bidyut Baran Saha ${ }^{1,4^{*}}$, Shigeru Koyama ${ }^{1,2,4}$ \\ ${ }^{1}$ Interdisciplinary Graduate School of Engineering Sciences, Kyushu University \\ 6-1 Kasuga-Koen, Kasuga-shi, Fukuoka 816-8580, Japan \\ ${ }^{2}$ Faculty of Engineering Sciences, Kyushu University \\ 6-1 Kasuga-Koen, Kasuga-shi, Fukuoka 816-8580, Japan \\ ${ }^{3}$ Mechanical Power Engineering Department, Mansoura University, El-Mansoura 35516, Egypt \\ ${ }^{4}$ International Institute for Carbon-Neutral Energy Research (WPI-I ${ }^{2} \mathrm{CNER}$ ), Kyushu University \\ 744 Motooka, Nishi-ku, Fukuoka 819-0395, Japan \\ *Author to whom correspondence should be addressed, \\ E-mail: saha.baran.bidyut.213@m.kyushu-u.ac.jp
}

(Received January10, 2014; accepted February 6, 2014)

\begin{abstract}
Adsorption isotherms of ethanol onto surface treated activated carbons, namely $\mathrm{H}_{2}$ treated Maxsorb III and $\mathrm{KOH}-\mathrm{H}_{2}$ treated Maxsorb III have been investigated experimentally. The magnetic suspension adsorption measurement unit of type MSB-VG-S2 is used for measuring the equilibrium uptake over adsorption temperatures range from 30 to $70{ }^{\circ} \mathrm{C}$ and evaporation temperatures between -6 and $65{ }^{\circ} \mathrm{C}$. The Dubinin-Radushkevich (D-R) and Dubinin-Astakhov (D-A) adsorption isotherm models are used to correlate the experimental data and to draw pressure-temperature-concentration (P-T-W) diagrams of the assorted pairs. Employing a time independent thermodynamic model, the coefficient of performance (COP) and specific cooling capacity (SCE) of the ideal adsorption cooling cycle has also been studied. Theoretical results show that the cycle performance using $\mathrm{H}_{2}$-Maxsorb III/ethanol pair is superior to that of $\mathrm{KOH}-\mathrm{H}_{2}-\mathrm{Maxsorb} \mathrm{III} / \mathrm{ethanol}$ pair.
\end{abstract}

Key words: thermodynamic analysis, adsorption isotherm, ethanol, ideal cooling cycle

\section{Introduction}

Adsorption refrigeration and heat pump systems powered by waste heat with utilizing environment friendly adsorbents and refrigerants pairs received great attention in the past few decades. Before 1970s most of the adsorption study did exists for gas separation, purification and for catalysis, very few studies did exist on adsorption refrigeration system ${ }^{1)-6}$. But intensified efforts were taken on the thermally powered system after the imposition of international restrictions on the production and use of CFCs (chlorofluoro-carbons) and HCFCs (hydrochlorofluoro-carbons). These two gases are identified as the major contributors to deplete the ozone layer around the globe and taking part in the global warming. After the Montreal protocol in 1987, a new chance is given to the adsorptive system with objective of a rational use of primary energy; the objective being to use either solar energy or waste heat to drive the refrigerators or heat pumps. The main advantage of solid sorption refrigeration cycles is that they can be operated with heat sources temperature typically about $100{ }^{\circ} \mathrm{C}$, which is available in plenty of process industries or any other form of waste heat. However the main drawbacks of adsorption cooling/heat pump system is their poor performance in terms of cooling capacity and coefficient of performance (COP), thus a considerable performance enhancement is necessary to make the system economically competitive $^{7)}$.

Last few decades, much theoretical and experimental work has been done to develop the adsorption refrigeration systems which are in terms of different working pairs, system design and methodology. 


\section{Nomenclature}

\begin{tabular}{|c|c|}
\hline $\mathrm{A}$ & adsorption potential $[\mathrm{J} / \mathrm{mol}]$. \\
\hline COP & coefficient of performance \\
\hline $\mathrm{C}_{\mathrm{p}, \mathrm{ref}}$ & specific heat of refrigerant $[\mathrm{J} / \mathrm{kg} \mathrm{K}]$ \\
\hline $\mathrm{C}_{\mathrm{p}, \mathrm{s}}$ & specific heat of adsorbent $[\mathrm{J} / \mathrm{kg} \mathrm{K}]$ \\
\hline $\mathrm{C}_{\mathrm{p}, \mathrm{bed}}$ & specific heat of bed $[\mathrm{J} / \mathrm{kg} \mathrm{K}]$ \\
\hline $\mathrm{E}$ & $\begin{array}{l}\text { adsorption characteristic parameter } \\
{[\mathrm{J} / \mathrm{mol}]}\end{array}$ \\
\hline$\Delta \mathrm{h}$ & evaporation heat $[\mathrm{J} / \mathrm{kg}]$ \\
\hline $\mathrm{M}_{\mathrm{s}}$ & mass of adsorbent $[\mathrm{kg}]$ \\
\hline $\mathrm{M}_{\mathrm{bed}}$ & mass of bed $[\mathrm{kg}]$ \\
\hline$P_{\text {ads }}$ & $\begin{array}{l}\text { saturation pressure of refrigerant at } \\
\text { adsorption temperature }[\mathrm{kPa}]\end{array}$ \\
\hline$P_{\text {eva }}$ & equilibrium pressure of refrigerant $[\mathrm{kPa}]$ \\
\hline $\mathrm{Q}_{\mathrm{des}}$ & desorption Heat $[\mathrm{J} / \mathrm{kg}]$ \\
\hline$Q_{\text {st }}$ & isosteric heat $[\mathrm{J} / \mathrm{kg}]$ \\
\hline $\mathrm{Q}_{\mathrm{sh}}$ & sensible heat $[\mathrm{J} / \mathrm{kg}]$ \\
\hline $\mathrm{Q}_{\text {sh,pr }}$ & sensible hat during pre-heating $[\mathrm{J} / \mathrm{kg}]$ \\
\hline $\mathrm{Q}_{\text {sh,des }}$ & sensible heat during desorption $[\mathrm{J} / \mathrm{kg}]$ \\
\hline $\mathrm{R}$ & gas constant $[\mathrm{J} / \mathrm{mol} . \mathrm{K}]$ \\
\hline SCE & specific cooling effect $[\mathrm{J} / \mathrm{kg}]$ \\
\hline $\mathrm{T}_{\mathrm{ads}}$ & adsorption temperature $[\mathrm{K}]$ \\
\hline $\mathrm{T}_{\mathrm{des}}$ & desorption temperature $[\mathrm{K}]$ \\
\hline $\mathrm{W}$ & equilibrium uptake $[\mathrm{kg} / \mathrm{kg}]$ \\
\hline $\mathrm{W}_{0}$ & maximum adsorption capacity $[\mathrm{kg} / \mathrm{kg}]$ \\
\hline $\mathrm{W}_{\max }$ & maximum uptake $[\mathrm{kg} / \mathrm{kg}]$ \\
\hline $\mathrm{W}_{\min }$ & minimum uptake $[\mathrm{kg} / \mathrm{kg}]$ \\
\hline
\end{tabular}

Sakoda and Suzuki ${ }^{8)}$ proposed a transient simulation model for adsorption cooling cycle using silica gel water pair which is powered by solar energy.

Boelman et al. ${ }^{9)}$ and Saha et al. ${ }^{10)}$ investigated experimentally and analytically the system performance of two-bed single stage silica gel - water based adsorption cooling systems. El-Sharkawy et al. ${ }^{11), 12)}$ investigated the performance of ideal adsorption cooling cycle employing activated carbon ethanol pair which is attractive for solar adsorption cooling application. Miyazaki et al. ${ }^{13)}$ evaluated the performance of innovative dual evaporator type three-bed adsorption chiller for cooling application where they found more than $50 \%$ improvement of system performance over two-bed single stage chiller. Saha et al. ${ }^{14)}$ also evaluated the performance of low temperature waste heat driven multi-bed silica gel - water adsorption chiller and showed the system can work even if the heat source temperature is $60{ }^{\circ} \mathrm{C}$. Uddin et al. ${ }^{15)}$ analytically investigated the performance of adsorption-compression hybrid system which can save $30 \%$ energy compared to the conventional system under same operating condition. In designing and developing adsorption cooling system, the adsorption characteristics of the adsorbate - adsorbent pair provides the key information. Chua et al. ${ }^{16)}$ experimentally measured the adsorption characteristic of silica gel - water system at temperature range 25 to $65^{\circ} \mathrm{C}$, Himeno et al. ${ }^{17)}$ measured high pressure excess equilibria of methane and carbon dioxide on five microporous activated carbons at temperature range 0 to $60{ }^{\circ} \mathrm{C}$. El-Sharkawy et al. ${ }^{18)}$ experimentally measured the adsorption characteristics of ethanol and activated carbon fibers at temperature range 11 to $60{ }^{\circ} \mathrm{C}$. Saha et al. ${ }^{19)}$ measured the adsorption characteristics and heat of adsorption of $\mathrm{R}-134 \mathrm{a}$ on activated carbon at temperature range of $5-70{ }^{\circ} \mathrm{C}$.

In the present study, adsorption isotherms are measured experimentally following evaporation temperature ranges from -6 to $65{ }^{\circ} \mathrm{C}$ and adsorption temperature 30 to $70{ }^{\circ} \mathrm{C}$ for a possible use in adsorption cooling system application. The isotherms data are correlated using the D-R and D-A equations from which $\mathrm{P}-\mathrm{T}-\mathrm{W}$ diagrams are plotted. The performance of a single stage ideal adsorption system for $\mathrm{H}_{2}$-Maxsorb III/ethanol and $\mathrm{KOH}-\mathrm{H}_{2}-$ Maxsorb III/ethanol pairs is also investigated.

\section{Materials}

The adsorbent activated carbon powder, namely Maxsorb III, has been supplied by Kansai Coke and Chemicals Co. Ltd. with surface area $3045 \mathrm{~m}^{2} / \mathrm{g}$ and micropore volume $1.7 \mathrm{~cm}^{3} / \mathrm{g}$. During surface treatment, the parent Maxsorb III is placed in a reduction environmental condition $\left(\mathrm{Ar} / \mathrm{H}_{2}=8 / 2(\mathrm{v} / \mathrm{v})\right)$ at $600^{\circ} \mathrm{C}$ for $24 \mathrm{~h}$, where the sample is named $\mathrm{H}_{2}$-Maxsorb III. Potassium hydroxide $(\mathrm{KOH})$ treatment was applied to $\mathrm{H}_{2}$-Maxsorb III at $600-750^{\circ} \mathrm{C}$ for $1 \mathrm{~h}$ under nitrogen flow to get the higher contents of oxygen containing functional groups which is namely $\mathrm{KOH}-\mathrm{H}_{2}-\mathrm{Maxsob}$ III $^{20)}$. The elemental composition of the treated sample was measured by a CHN analyzer which is summarized in Table1.

The parent Maxsorb III contains $0.13 \%$ of ash and $4.35 \%$ of oxygen whereas the surface treated Maxsorb III does not contain any ash, however, the oxygen contents changes for $\mathrm{H}_{2}$-Maxsorb III and $\mathrm{KOH}-\mathrm{H}_{2}-$ Maxsorb III after the treatment (see Table 1). During treatment some pore wall of Maxsorb III, which is composed of defective and thin fragile graphite sheet, gasified easily giving small decrease of specific surface area. The micropore volume of $\mathrm{H}_{2}$-Maxsorb III and $\mathrm{KOH}-\mathrm{H}_{2}-$ Maxsorb III is 1.73 and $1.65 \mathrm{~cm}^{3} / \mathrm{g}$, respectively. 


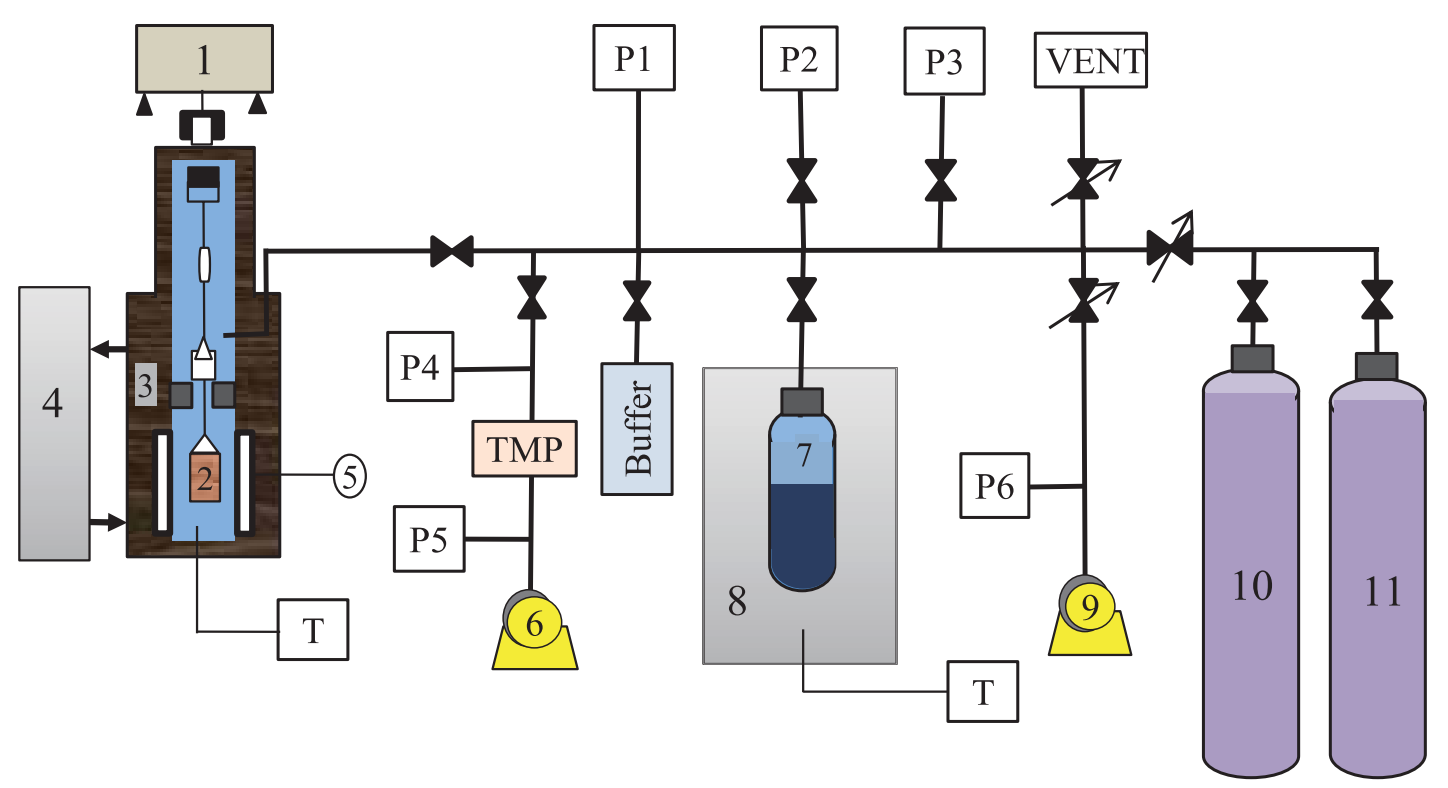

1. Magnetic suspension balance unit, 2.Sample cell, 3. Circulation oil jacket, 4. Isothermal oil bath, 5. Sheathed heater used during regeneration, 6,9. Rotary and Diaphragm pump, respectively, 7. Refrigerant pool, 8. Isothermal oil bath, 10. Nitrogen, 11. Helium, TMP- Terbo-molecular pump, T- Thermocouple. P- Pressure gauge.

Fig. 1 Schematic diagram of the experimental apparatus.

The refrigerant has been used in the present study is ethanol with purity $99.5 \%$ (vol.) which is supplied by Osaka Kishida Chemical Co. Ltd. During system performance analysis, the thermophysical properties of ethanol were evaluated using Refprop version $9^{21}$.

Table 1 Elemental composition of adsorbents.

\begin{tabular}{lccccc}
\hline \multirow{2}{*}{ Sample } & \multicolumn{4}{c}{ Elemental composition } & \multirow{2}{*}{$\begin{array}{c}\text { Surface } \\
\text { area }\end{array}$} \\
\cline { 2 - 5 } & $\begin{array}{c}\mathrm{C} \\
{[\%]}\end{array}$ & $\begin{array}{c}\mathrm{H} \\
{[\%]}\end{array}$ & $\begin{array}{c}\mathrm{N} \\
{[\%]}\end{array}$ & $\begin{array}{c}\mathrm{O} \\
{[\%]}\end{array}$ & {$\left[\mathrm{m}^{2} / \mathrm{g}\right]$} \\
\hline $\mathrm{H}_{2}$-MaxsorbIII & 97.91 & 0.22 & 0.12 & 1.75 & 3029 \\
\hline $\begin{array}{l}\text { KOH-H } \\
\text {-Maxsorb III }\end{array}$ & 89.15 & 0.27 & 0.08 & 10.5 & 2992 \\
\hline
\end{tabular}

\section{Experiment}

The adsorption characteristics of ethanol onto surface treated activated carbons were measured by a magnetic suspension adsorption measurement unit. The experiment was conducted using the multi-step technique within evaporation temperature between -14 and $77^{\circ} \mathrm{C}$ and adsorption temperature in the range of 20 to $80{ }^{\circ} \mathrm{C}$. In each step adsorption temperature was kept constant and evaporation temperature increased step by step until reaching relative pressure of about 0.9 . Before starting adsorption the sorbent was first heated at $120{ }^{\circ} \mathrm{C}$ for 4 hours under vacuum condition of $3 \times 10^{-4} \mathrm{~Pa}$ to remove any adsorbed gas inside the sample. As the weight measurement method is influenced by the buoyancy force so the effect of buoyancy is considered during measurements. The schematic diagram of the experimental apparatus is shown in Fig.1, where an isothermal air bath is used to avoid the condensation inside the connecting tube by setting the bath temperature $20^{\circ} \mathrm{C}$ higher than the saturation temperature of the vapor. A detailed description of the experimental procedure can be found elsewhere ${ }^{22)}$.

\section{Results and discussion}

\subsection{Adsorption isotherm}

To correlate the adsorption isotherm data, the Dubinin-Radushkevich (D-R) and Dubinin - Astakhov $(\mathrm{D}-\mathrm{A})^{23)}$ equations (Eqs. 1 and 2) are found to be suitable.

$$
\begin{aligned}
& W=W_{0} \exp \left[-D\left(T \ln \left(\frac{P_{a d s}}{P_{\text {eva }}}\right)\right)^{2}\right] \\
& W=W_{0} \exp \left[-\left\{\frac{A}{E}\right\}^{n}\right]
\end{aligned}
$$

Where $\mathrm{A}$ is the adsorption potential that can be estimated as;

$$
A=R T_{a d s} \ln \left(\frac{P_{a d s}}{P_{e v a}}\right)
$$

Where $W$ stands for the equilibrium uptake $[\mathrm{kg} / \mathrm{kg}$ ] for the adsorbent/refrigerant pair, $W_{0}$ defines the maximum adsorption capacity $[\mathrm{kg} / \mathrm{kg}], D$ is an adsorption parameter that depends on the adsorbent/adsorbate pair $\left[\mathrm{K}^{-2}\right], \quad E$ is the adsorption characteristic parameter 
[J/mol.]. In Eq. (3), $T_{a d s}$ is the adsorption temperature [K], $P_{a d s}$ and $P_{e v a}$ defines the saturation pressure of refrigerant at adsorption temperature and equilibrium pressure at evaporation temperature $[\mathrm{kPa}]$, respectively. The exponential parameter $n$ gives the best fitting of $\ln (W)$ versus $A^{n}$ plot in Eq. (4).

Logarithmic form of Eq. (2) is

$\ln W=\ln W_{0}-\frac{1}{E^{n}}\left\{R T_{a d s} \ln \left(\frac{P_{a d s}}{P_{e v a}}\right)\right\}^{n}$

Experimentally measured equilibrium data are correlated with D-R and D-A equations and the numerical values of fitting parameters are furnished in Table 2 .

Table 2 Fitting parameters of D-R and D-A equation.

\begin{tabular}{ccccc}
\hline Adsorbents & $\begin{array}{c}W_{0} \\
{[\mathrm{~kg} / \mathrm{kg}]}\end{array}$ & $\begin{array}{c}n \\
{[-]}\end{array}$ & $\begin{array}{c}D \\
{\left[K^{-2}\right]}\end{array}$ & $\begin{array}{c}E \\
{[\mathrm{~J} / \mathrm{mol}]}\end{array}$ \\
\hline $\mathrm{H}_{2}$-Maxsorb III & 1.23 & & $\begin{array}{c}1.57 \\
\times 10^{-6}\end{array}$ & \\
\hline $\begin{array}{c}\text { KOH-H } \\
\text { Maxsorb III }\end{array}$ & 1.0 & 1.9 & & 7002 \\
\hline
\end{tabular}

It is found that the maximum adsorption uptake for $\mathrm{H}_{2}$-Maxsorb III is higher than the $\mathrm{KOH}-\mathrm{H}_{2}-\mathrm{Maxsob}$ III (see Table 2), which follows the order of surface area and micro pore volume of the sample. The adsorption isotherms of $\mathrm{H}_{2}$-Maxsorb III/ethanol and $\mathrm{KOH}-\mathrm{H}_{2}-\mathrm{Maxsob} \mathrm{III} /$ ethanol pairs are shown in Figs. 2(a) and (b), respectively.

\subsection{Isosteric heat of adsorption}

The Isosteric heat of adsorption $\left(Q_{s t}\right)$ is defined as the difference between the activation energy for adsorption and desorption. The value of $Q_{s t}$ is very important for kinetic studies of adsorption process because the heat released upon adsorption is partially adsorbed by the adsorbent which causes a rise in adsorbent temperature and thus influences the rate of adsorption.

The numerical values of isosteric heat of adsorption at constant uptake is estimated from equilibrium data using Clausious - Clapeyron equation which is given by

$\frac{-Q_{s t} M}{R}=\frac{\partial \ln P_{e v a}}{\partial\left(\frac{1}{T_{a d s}}\right)}$

Where $Q_{s t}$ is the isosteric heat of adsorption $[\mathrm{J} / \mathrm{kg}] . R$ is the gas constant $[\mathrm{J} /(\mathrm{mol} . \mathrm{K})], M$ is molar constant [kg/mol.]. The measured values of $Q_{s t}$ for $\mathrm{H}_{2}$-Maxsorb III/ethanol and $\mathrm{KOH}-\mathrm{H}_{2}-\mathrm{Maxsorb}$ III/ethanol pairs are $1035[\mathrm{~kJ} / \mathrm{kg}]$ and $1037[\mathrm{~kJ} / \mathrm{kg}]$, respectively.

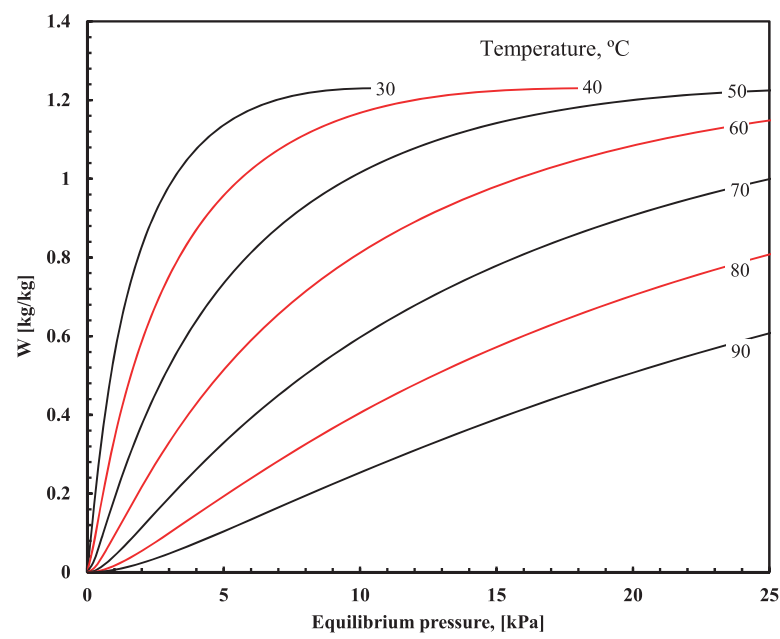

Fig. 2(a) Adsorption isotherms of $\mathrm{H}_{2}$-Maxsorb III/ethanol pair as predicted by D-R equation.

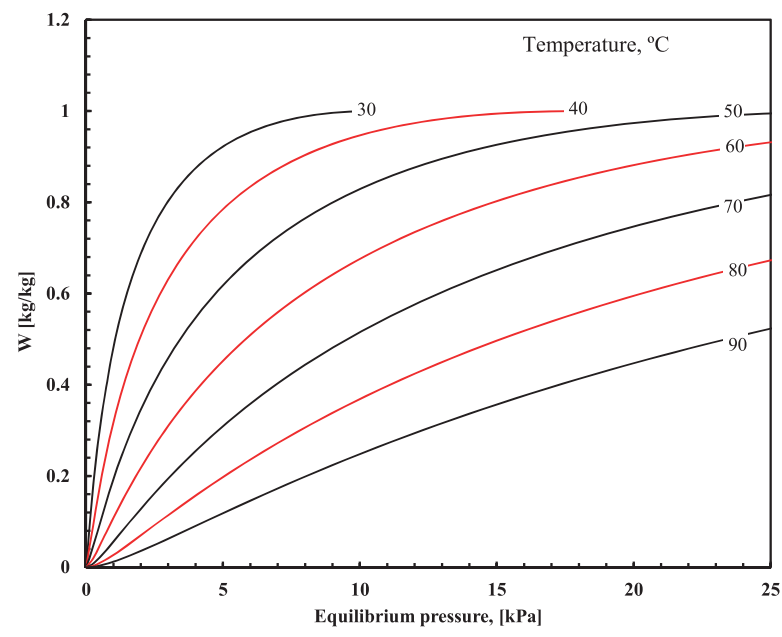

Fig. 2(b) Adsorption isotherms of $\mathrm{KOH}-\mathrm{H}_{2}-\mathrm{Maxsorb}$ III/ethanol pair as predicted by D-A equation.

\subsection{Thermodynamic cycle}

Figs. 3 (a) and (b) show the schematic diagrams of a single bed basic cycle with adsorption and desorption mode, respectively. Each cycle mainly consists of three heat exchangers, namely an evaporator, a condenser and an adsorber/desorber heat exchanger (sorption element). The condenser and the evaporator are connected through a throttling valve or a bending capillary tube. Here the basic cycle is assumed to be an ideal and as consequence, the pressure drops as well as the heat loss are neglected.

The equilibrium adsorption cycle is best understood using the P-T-W diagram which shows the relationship between the equilibrium pressure, adsorbent temperature and adsorption capacity at equilibrium state conditions. The cycle processes can be presented on this diagram which makes it possible to estimate the performance of adsorption cycle. In the present study, the D-R and D-A equations are used to plot the P-T-W diagrams of $\mathrm{H}_{2}$-Maxsorb III/ethanol and $\mathrm{KOH}-\mathrm{H}_{2}-\mathrm{Maxsob}$ III/ethanol pairs which are presented in Figs. 4 (a) and (b), 
respectively. Where, the concentration is kept constant and the equilibrium pressure is calculated at different values of adsorption temperatures. The ideal cycle for the same adsorbent-refrigerant pair is super imposed in the same figure. It can be seen from Figs. 4(a) and (b) that the concentration difference for $\mathrm{H}_{2}$-Maxsorb III/ethanol pair is about $20 \%$ higher than that of $\mathrm{KOH}-\mathrm{H}_{2}-\mathrm{Maxsorb}$ III/ethanol pair in the same operating condition, demonstrating the superiority in cooling applications. In addition to uptake difference, the adsorption kinetics of assorted working pair is another essential parameter that needed to be considered during making a comparison between two working pairs. The aim of surface treatment on Maxsorb III is to increase the kinetics of assorted working pairs considering the oxygen content in the sample. The detailed analysis of kinetics will be studied by the present authors.

It can also be noticed from Figs. 4(a) and (b) that the cycle consists of two isosteric and two isobaric processes. In adsorption process $(a-b)$, the pressure is kept constant at $P_{\text {eva }}$. The refrigerant vapor evaporates in the evaporator picking up its latent heat from the chilled water then, adsorbed by the adsorber via the valve $V 1$ (see Fig. 3(a)). The refrigerant concentration in the adsorber increases from $W_{\min }$ to $W_{\max }$. In Pre-heating $(b-c)$ process, both the valves $V 1$ and $V 2$ are closed and the adsorber is heated at constant concentration using a high temperature heat source and hence the pressure increases from $P_{e v a}$ to $P_{c o n}$. In desorption process $(c-d)$, the refrigerant regenerates and condenses on the condenser at pressure $P_{c o n}$ via the valve $V 2$ (see Fig. 3(b)). The refrigerant concentration on the desorber decreases from $W_{\max }$ to $W_{\min }$. In pre-cooling process $(d-a)$, the adsorbent bed is cooled at constant concentration which makes the pressure decrease from $P_{c o n}$ to $P_{\text {eva }}$.

The model described here is a thermodynamically equilibrium model. This means, all the thermal contributions are calculated based on heat and mass balance provided by the (P-T-W) diagrams.

Cooling effect can be estimated as,

$$
Q_{C}=M_{s}\left(W_{\max }-W_{\min }\right)\left[\Delta h_{\text {eva }}-\int_{T_{\text {eva }}}^{T_{a d s}} C_{p, r e f} d T\right]
$$

Where $M_{s}$ is the mass of the sample adsorbent, $W_{\max }$ and $W_{\min }$ is the maximum and minimum sorption uptake, respectively.

$\Delta h_{\text {eva }}$ is the vaporization enthalpy and $C_{p, r e f}$ is specific heat of refrigerant.

Desorption heat, $Q_{d e s}=M_{s} Q_{s t}\left(W_{\max }-W_{\min }\right)$

$W_{\text {max }}=W_{0} \exp \left[-\left\{\frac{R T_{a d s}}{E} \ln \left(\frac{P_{a d s}}{P_{\text {eva }}}\right)\right\}^{n}\right]$

$W_{\text {min }}=W_{0} \exp \left[-\left\{\frac{R T_{\text {des }}}{E} \ln \left(\frac{P_{\text {des }}}{P_{\text {con }}}\right)\right\}^{n}\right]$

Sensible heat, $Q_{s h}=Q_{s h, p r}+Q_{\text {sh,des }}$

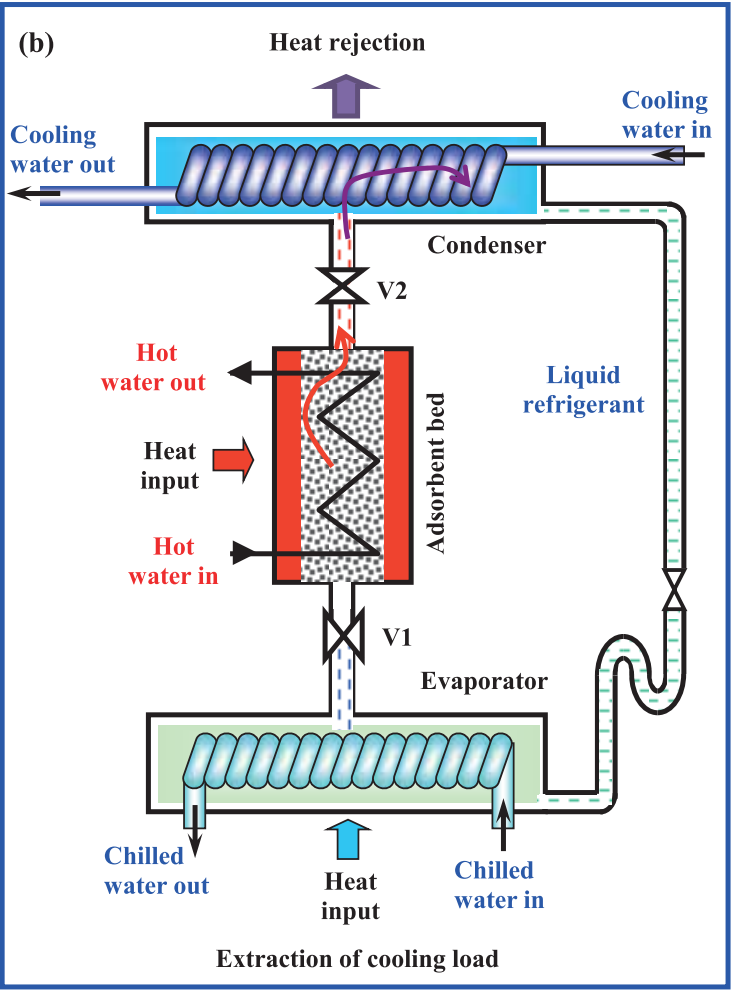

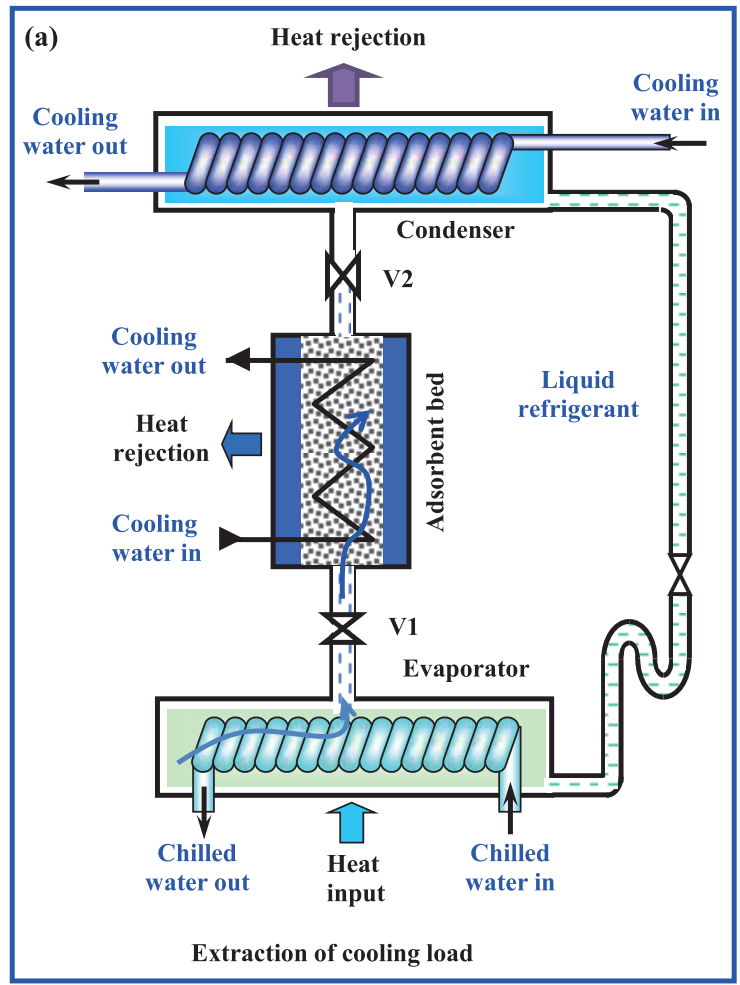

Fig. 3 Schematic diagram of ideal adsorption cooling cycle (a) adsorption mode, (b) desorption mode 


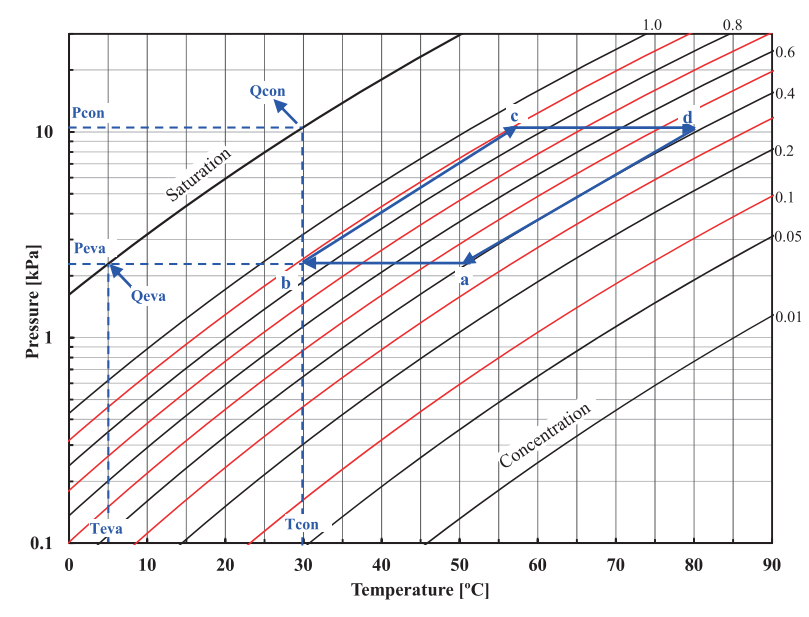

Fig. 4(a) P-T-W diagram of $\mathrm{H}_{2}$-Maxsorb III/ethanol pair.

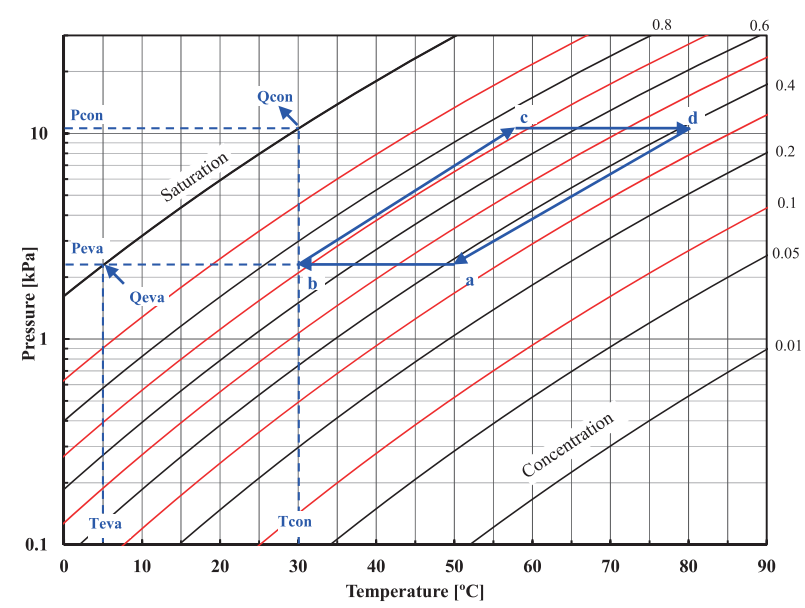

Fig. 4(b) P-T-W diagram of $\mathrm{KOH}-\mathrm{H}_{2}-\mathrm{Maxsorb}$ III/ethanol pair.

Sensible heat during pre-heating,

$$
\begin{aligned}
Q_{s h, p r}= & M_{s} \int_{T_{b}}^{T_{c}} C_{p, s} d T+M_{s} W_{\max } \int_{T_{b}}^{T_{c}} C_{p, r e f} d T \\
& +M_{b e d} \int_{T_{b}}^{T_{c}} C_{p, b e d} d T
\end{aligned}
$$

Sensible heat during desorption,

$$
\begin{aligned}
Q_{s h, d e s}= & M_{s} \int_{T_{c}}^{T_{d}} C_{p, s} d T+M_{s} \frac{W_{\max }-W_{\min }}{2} \int_{T_{c}}^{T_{d}} C_{p, r e f} d T \\
& +M_{b e d} \int_{T_{c}}^{T_{d}} C_{p, b e d} d T
\end{aligned}
$$

The specific cooling effect $(S C E)$ and the coefficient of performance $(C O P)$ of the time independent ideal adsorption cycle is calculated using the following equations:

$$
\begin{aligned}
& S C E=\left(W_{\max }-W_{\min }\right)\left[\Delta h_{\text {eva }}-\int_{T_{\text {eva }}}^{T_{\text {con }}} C_{p, r e f} d T\right] \\
& C O P=M_{s} \frac{S C E}{Q_{\text {des }}+Q_{\text {sh }}}
\end{aligned}
$$

For simplicity, the thermal capacity of the adsorption bed is considered two times that of thermal capacity of the adsorbent.

Fig. 5. Shows the variation of $S C E$ with desorption temperature for five different adsorbents/ethanol pairs at evaporation temperature $5{ }^{\circ} \mathrm{C}$. The value of $S C E$ increases linearly with the increase of desorption temperature. This is due to the concentration difference with increase of regeneration temperature at constant adsorption and evaporation temperature. It can be seen from the figure that the $S C E$ values for $\mathrm{H}_{2}$-Maxorb III is higher than the other studied working pairs.

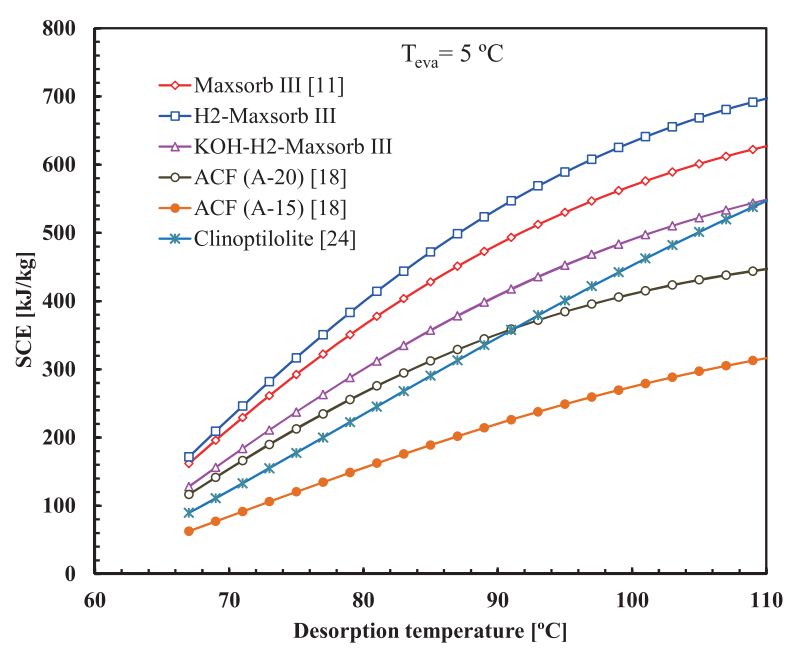

Fig. 5 Effect of desorption temperature on specific cooling effect.

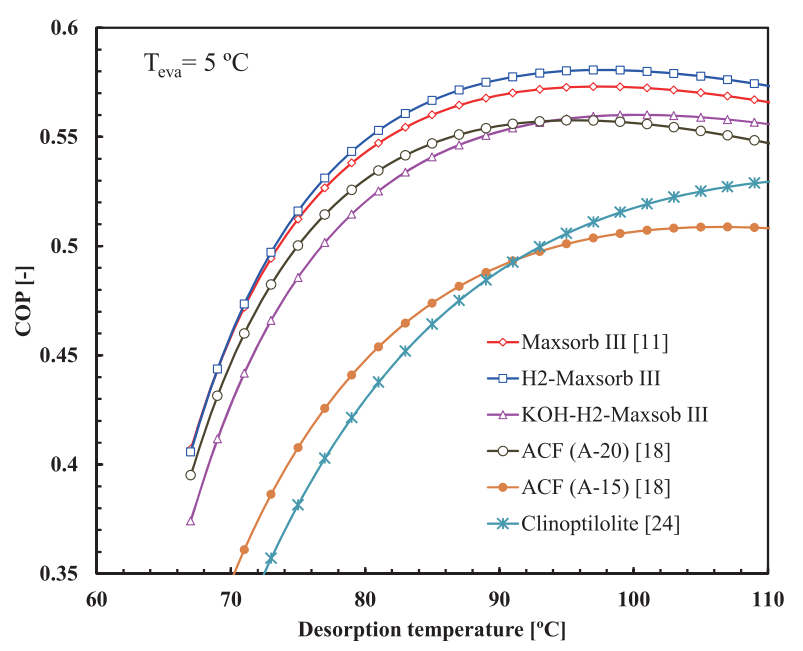

Fig. 6 Effect of desorption temperature on COP. 
Fig. 6 shows the variation of coefficient of performance with desorption temperature at evaporation temperature $5{ }^{\circ} \mathrm{C}$. It can be noticed that the $C O P$ increases sharply only when the desorption temperature is below $90{ }^{\circ} \mathrm{C}$. After that there is no significant change in $C O P$ even though $S C E$ increases. This is happened due to the requirement of heat input becomes significantly large when the temperature difference between heat source and heat sink becomes higher than $60{ }^{\circ} \mathrm{C}$.

\section{Conclusions}

Adsorption isotherms of $\mathrm{H}_{2}$-Maxsorb III and $\mathrm{KOH}-\mathrm{H}_{2}-\mathrm{Maxsorb}$ III with ethanol have been measured experimentally using a magnetic suspension adsorption measurement unit. Experimental results show that, the maximum adsorption capacity of $\mathrm{H}_{2}$ treated Maxsorb III/ethanol pair is about $1.23 \mathrm{~kg} / \mathrm{kg}$ whilst $\mathrm{KOH}-\mathrm{H}_{2}$ treated Maxsorb III/ethanol has maximum adsorption capacities of $1.0 \mathrm{~kg} / \mathrm{kg}$. The Dubinin-Radushkevich and the Dubinin-Astakhov equations are used to correlate the equilibrium uptake data and to plot P-T-W diagrams of assorted pairs. Thermodynamic analysis shows that the $\mathrm{H}_{2}$-Maxsorb III/ethanol adsorption cycle can achieve a $\mathrm{COP}$ as high as 0.58 with a regeneration temperature below $100{ }^{\circ} \mathrm{C}$ along with a coolant at $30^{\circ} \mathrm{C}$ whereas the $\mathrm{KOH}-\mathrm{H}_{2}-\mathrm{Maxsorb} \mathrm{III} / \mathrm{ethanol}$ pair can achieve COP 0.56 . It is also found that SCE of ideal cycle using $\mathrm{H}_{2}$-Maxsorb III/ethanol pair is superior to that of $\mathrm{KOH}-\mathrm{H}_{2}-\mathrm{Maxsorb} \mathrm{III} / \mathrm{ethanol}$ pair.

\section{Acknowledgement}

This work was financially supported by Japan Science and Technology Agency (JST), Core Research for Evolutional Science and Technology (CREST).

\section{References}

1) E. B. Miller. Am. Soc. Refrig. Eng., 17, 103 (1929).

2) A. Aittomaki and M. Hakonen, Int. J. Refrig, 9, 240 (1986).

3) F. Meunier, Sep. Technol., 3, 143 (1993).

4) R. E. Critoph, Carbon, 27, 63 (1986).

5) F. Meunier, Heat Recovery Syst. CHP, 13, 289 (1993).

6) G. Cacciola and G. Restuccia, Heat Recovery Syst., 14, 409 (1994).

7) H. Demir, M. Mobedi, S. Ülkü, Renew. Sustain. Energy. Rev., 12, 2381 (2008).

8) A. Sakoda, M. Suzuki, J. Chem. Eng. Jpn., 17, 52 (1984).
9) E. C. Boelman, B. B. Saha, T. Kashiwagi, ASHRAE Trans, 101, 358 (1995).

10) B. B. Saha, A. Akisawa, T. Kashiwagi, Energy, 22, 437 (1997).

11) I. I. El-Sharkawy, B. B. Saha, S. Koyama, J. He, K.C. Ng, C. Yap, Int. J. Refrig, 32, 1407 (2008).

12) I. I. El-Sharkawy, M. Hassan, B. B. Saha, S. Koyama, M. M. Nasr, Int. J. Refrig, 32, 1579 (2009).

13) T. Miyazaki, A. Akisawa, B. B. Saha, Int. J. Refrig, 33, 276 (2010).

14) B. B. Saha, S. Koyama, J. B. Kee, K. Kuwahara, K. C. A Alam, Y. Hamamoto, A. Akisawa, T. Kashiwagi, Int. J. Multiphase Flow, 29, 1249 (2003).

15) K. Uddin, T. Miyazaki, S. Koyama, B. B. Saha, Int. J. of Air-Con. Refrig, accepted, 21, (2013) .

16) T. H. Chua, K.C. Ng, A. Chakraborty, N.M. Oo, M.A. Othman, J. Chem. Eng. Data, 47, 1177 (2002).

17) S. Himeno, T. Komatsu, S. Fujita, J. Chem. Eng. Data, 50, 369 (2005).

18) I. I. El-Sharkawy, K. Kuwahara, B. B. Saha, S. Koyama, K. C. Ng, Appl. Therm. Eng. 26, 859 (2006).

19) B.B. Saha, K. Habib, I. I. El-Sharkawy, S. Koyama, Int. J. Refrig, 32, 1563 (2009).

20) H.S. Kil, K. Hata, K. Ideta, J. Miyawaki, I. Mochida, S.H. Yoon, Proc. IMPRES 2013, Fukuoka, 525 (2013).

21) E.W. Lemmon, M.O. McLinden, M.L. Huber, Reference fluid thermodynamic and transport properties (Refprop) version 9, Phys. Chem. Prop. Div. NIST (2010).

22) K. Uddin, T. Miyazaki, B. B. Saha, S. Koyama, H.S Kil, J. Miyawaki, S.H. Yoon, Proc. IMPRES 2013, Fukuoka, 357 (2013).

23) D. D. Do, Adsorption Analysis: Equilibria and Kinetics, Series on Chem. Eng. Vol. 2, Imperial College Press, London (1998).

24) E. Ivanova, M. Karsheva, Sep. Purif. Technol., 73, 429 (2010). 